\title{
Short-stay facilities in accident and emergency departments for children
}

\author{
T. F. BEATTIE, J. FERGUSON, \& P. A. MOIR \\ Accident \& Emergency Department, Royal Aberdeen Chidren's Hospital, Aberdeen
}

\section{SUMMARY}

This paper assesses short stay ward facilities for children in the United Kingdom. The results of a postal questionnaire indicate that $50 \%$ of departments surveyed have a short-stay ward. Of these $25 \%$ admit small numbers of children. These are mainly children who have sustained trauma-related problems. The potential role of paediatric short-stay ward facilities is discussed.

\section{INTRODUCTION}

Early reports on accident and emergency (A\&E) services suggested improvements in patient care by the development of observation wards (Lewin, 1978; Nuffield Provincial Hospitals Trust, 1960) which subsequently have been shown to be of benefit particularly for elderly patients (Dallos \& Mouzas, 1981; Harrop \& Morgan, 1985). There has been no study of the value of a short-stay ward for children. The purpose of this study was to identify the number of departments which have a short-stay facility for children and who they admit.

\section{METHODS}

A questionnaire (Fig. 1) was sent to 100 A\&E consultants selected at random. Where two consultants were selected but were known to work in the same department a coin was tossed to decide which one would receive the form. There was no prior selection as to whether consultants worked in exclusively paediatric

Correspondence: $M r$ T. F. Beattie, Accident \& Emergency Department, Royal Aberdeen Children's Hospital, Cornhill Road, Aberdeen, AB9 2ZG. 
Fig. 1. Questionnaire sent to $100 \mathrm{A \& E}$ consultants who were selected at random

(1) Do you have a short-stay ward attached to your A\&E department?

Yes/No*

(2) If so do you admit children?

Yes/No

(3) If yes what categories do you admit? (Please tick)
Head injury
Poisoning
Fractures
Soft tissue infections
Hand injuries
Infectious diseases $\square$
Other (Please specify)

Abdominal pain

Urti

Meningitis

Social

Post-operative cases

Burns

(4) If children are admitted to your ward how many nurses hold a 'sick childrens' qualification?

(5) How many children do you admit each year?

* Please delete as appropriate

THANK YOU

A\&E departments, in exclusively adult departments or in departments which catered for both adults and children.

For the purposes of this study, all beds available to the A\&E consultant, whether they were directly attached to the A\&E department or on other wards werहु considered short-stay ward facilities.

\section{RESULTS}

Of the 100 questionnaires sent out 90 were returned. All forms returned had sufficient information to be entered into the analysis.

Of the 90 departments, 44 had a short-stay ward. Of these, 11 admitted children (12.2\% of the total), nine exclusively under A\&E care and two under joint care with paediatricians.

Nine consultants admitted head injuries, seven admitted soft tissue infections, six admitted burns, five admitted fractures and hand injuries, three admitted poisonings and one received children post-operatively. Three departments took children with social problems and two received children who were suspected of having sustained non-accidental injury. No department admitted children for investigation of meningitis, suspected upper respiratory tract infection, infectious diseases or abdominal pain.

Of those departments admitting children, four did not specify the number of children admitted. Of the rest two admitted less than 50 per year, four admitted between 50 and 450 per year and only one admitted 450 children a year.

In three departments all nurses had sick children's training, three departments had one specialist nurse available, four did not know how many had special training and one department had none available. 


\section{DISCUSSION}

The Nuffield Steering Committee on casualty services visited 70 A\&E departments for its report in 1960. Of these, only one had short-stay ward facilities. This study indicates that in 1992 up to $50 \%$ of A\&E departments have short-stay ward facilities. However, of these only $25 \%$ provide facilities for children.

Previous reports have spoken favourably of the value of the short-stay ward. However to run effectively it needs adequate consultant and middle grade cover to ensure constant supervision of the ward. This is particularly so when weekend admissions are catered for. There is no doubt that many departments are overstretched at present and to develop short-stay wards would place an intolerable burden on them. Indeed some replies indicated that short-stay ward facilities had existed previously but had been withdrawn as economy measures by management!

Of those departments that do have short-stay wards which admit children, fractures, soft tissue injuries and head injuries form the bulk of the workload. These are areas in which A\&E consultants have expertise.

It has been argued that paediatricians should look after all children admitted to hospital. However their training in trauma and soft tissue injuries is less than that of A\&E consultants.

Other factors which may deter medical staff from admitting children would be the absence of paediatric-trained nurses and suitable accommodation. The authors endorse the view that children should not be admitted to an area where specialist paediatric nursing is absent.

It is also believed that children should be admitted to separate areas away from the adult population. This is in accordance with the views of the British Association for Emergency Medicine (formerly the Casualty Surgeons Association) in its joint report with the British Paediatric Association and the British Paediatric Surgeons Association (1988).

Where paediatric nurses and suitable accommodation are available we suggest that children can be admitted with minor problems under the care of A\&E consultants as suggested by Sainsbury \& Sibert (1984). Another study (Beattie \& Moir, 1993) indicates that over $90 \%$ of children admitted with minor injury or following a minor accident can be discharged from hospital within $24 \mathrm{~h}$. These are surely true short-stay patients.

These results indicate that there is scope for the development of paediatric Accident \& Emergency in-patient services.

\section{ACKNOWLEDGEMENTS}

Our thanks to Miss Rebecca Moir for preparing the manuscript and to all our colleagues who took time to return the questionnaires. 
180 T. F. Beattie et al.

\section{REFERENCES}

Beattie T. F. \& Moir P. A. (1993) Paediatric accident and emergency short-stay ward: a 1-year audit: Archives of Emergency Medicine 10, 181-186.

Casualty Surgeons Association (1988) Joint statement on childrens' attendances in Accident \& Emergenfy Departments. Joint statement between the British Paediatric Association, British Association Paediatric Surgeons and Casualty Surgeons Association.

Dallos V. \& Mouzas G. L. (1981) An evaluation of the functions of the short stay observation ward the Accident \& Emergency Department. British Medical Journal 282, 37-40.

Harrop S. N. \& Morgan W. J. (1985) Emergency care for the elderly in the short-stay ward of the Accident \& Emergency Department. Archives of Emergency Medicine 2, 141-147.

Lewin W. (1978) Medical staffing and Accident \& Entergency services. Joint Consultants Committee London.

Nuffield Provincial Hospitals Trust (1960) Casualty services and their setting: a study in medical care NPHT, London.

Sainsbury C. P. Q. \& Sibert J. R. (1984) How long do we need to observe head injuries in hospitā Archives of Disease in Childhood 59, 856-859. 